\title{
True Knowledge: The Supreme Purpose of Current Christian Education
}

\author{
Adrian Gheorghe Paul
}

\begin{abstract}
By true knowledge it is a necessity for humans, it is a longing and a fulfillment. It can not be achieved fully, only by the opening and the participation of man to God, the One who is the Subject that draws us to the true knowledge. If we understand that the truth is personified and fully incarnated into the divine Person of Jesus Christ ("I am the Truth" Jn 14:8), then by following him and His commandments and His Gospel's prescriptions, is a necessary object to follow toward achieving the full and satisfactory knowledge. Here, a decisive role occupies the Christian education, human formation after the image of the perfect model-Jesus Christ, the Son of God made man. Thus, we focus in this study on the formation of the new man in Christ through education, to understand the eternal Truth and to gain the true knowledge of realities.

KEY WORDS: Knowledge, participation, truth, Christian education, new man, supreme purpose.
\end{abstract}

\section{Introduction}

rom the start, we point out that it is not so simple, nor easy to $\boldsymbol{\Gamma}$ trace a synthetic situation, but completely, about what it means or implies the knowledge, the true knowledge of man, integrated in the Supreme Truth-Our Lord Jesus Christ, because of the complexity of the subject and the quantity basis concepts and arguments, either philosophical, or religious, or profane, involved. In an attempt to highlight such a situation, it can easily fall into sin 
of being generic and not succeed while emphasizing the essential elements of theological-dogmatic, spiritual, moral, philosophical or rational logic order, which applies to various aspects of the human condition and to social life.

Knowledge is a necessity. The humanity can not live without the knowledge. The surrounding reality, seen and unseen, is the object of knowledge. We are the object of knowledge for others, but also, our own object of knowledge. So, we are speaking about the reality from the "outside" and reality "from within" us. Both the one and the other, deeply and fully meaning of the word, we discover, we discern it, in relation to the divine element, to the Supreme Being of God. He is the subject, in our knowledge process. He can never be the object of knowledge. Knowing God, as the object of knowledge with our minds, is one of the major errors of discursive thought, which is why it will reduce God to the level of idea, an unmoved motor, absolute principle, Monad, vital principle that, trying to define, skipping on what He is and remains always the same-The living God.

Of course it is not to condemn the mind's attempt to know God. On the contrary. Only that we must keep in mind the fact that the knowledge of God is a commandment that we know it from the Divine Revelation, revealed fully in his Son, made man, who says: "This is eternal life: that they know You, the only true God, and Jesus Christ, whom You have sent." (In. 17:3) We can therefore confirm, without any mistake, that the purpose of all forms of knowledge of the unknown within us and around us, is the knowledge of God, the only true and full knowledge, made by the Revealer, par excellence, Jesus Christ, the Son of God incarnated. "The only Son, who is in closest relationship with the Father, has made Him known" (Jn. 1:18). This is why the knowledge of God is dependent totally of revelation and not of subjective meditation. We can not know God, only through the mind that is burned by discursive knowledge pride, continues until denying God. It is the failure of a mind that seeks to know God only with logical reason and reach to deny His existence, the mind becoming even the human self-sufficiency idol. Therefore it is requested to man, who is thirsty of knowing God, to know Him other than knowing things or other created beings. For if in knowing God we use only organs, functions and methods to knowing the relative, 
God will remain forever the Great Unknown, the Foreigner to our existence, impossible to encase in our limited concepts.

Therefore, we have the duty to know God, who is inconceivable, unknown and unreachable, through the reason enlightened by grace, because we are talking about knowledge not only intellectually, but with all the faculties of the spirit, with the whole enlightened being of grace, the one uncreated of God. By divine grace, the human reason is seeking to explain all, God is revealing to ourselves, as the mystery that includes and justifies everything. He is the living subject in the highest degree, in His eternal being and we tend to know Him, but this knowing it is not linked to the need for information, but to the need of salvation. Therefore, the knowledge of God is a process that actively involves Himself, through revelation. We know God through His grace, according to His full and authentic discoveries, for our salvation. For He reveals Himself to save us: "God, our Savior who wants all people to be saved and to come to a knowledge of the truth" (I Tim. 2:3-4).

\section{The Truth and the Supreme Knowledge}

When talking about "truth" and "knowledge" we understand all acts, employments and active implications of man, in its effort to implement in life and in facts, the prescriptions of God's Gospel, of God and of Our Savior, Jesus Christ and to sanctify ourselves, by acquiring the divine grace. Therefore His mission in this world is to reaffirm constantly the need to apply the Gospel's laws of Jesus Christ, in order to be formed in all systems and in all human societies, a spiritual progress and an human life adequate to the environment preparation for eternal life.

Certainly that the center of this trend and aspirations it holds the human being, more exactly the noble and sacred dignity of man made by "the image" of God and which is called to live the divine life in a perfect "resemblance" deification to Him. This represents the fulfillment from the man part of its final vocation, which is to respond concretely to the "invitation" that God makes to man, to assume the existence in communion with Him, in order to know Him. 
In this sense, we say that religious knowledge is a revelatory and participatory knowledge, where the communion and the community have a determinant role. It is revelatory because it is opened to us the chance to a participatory knowledge to life of God through Jesus Christ, His Son, into / through whom we can tell God: "My Lord and my God" (Jn. 20:28). Here's how true knowledge indicates the purpose for which man was made, defining it in his own vocation: "But just as he who called you is holy, so be holy in all you do" (I Peter $1: 15)$. In other words, the knowledge of God meaning the continues entering into the mystery of Unspoken presence and communion with Him, being the same thing with perfection.

The perfection of the word good, fully shows the value also as good, meaning that is found as the revelation of God's gifts, as gifts of our life, regarded from the perspective of eternal life. And as in any gift, the Giver himself send us a call, which is a part of good's content, then God is revealing to us, we come to understand His love divine call, that He always says. "For God so loved the world that He gave his one and only Son, that whoever believes in Him shall not perish but have eternal life" (Jn. 3:16). We therefore have the sacred duty to value the gift received in the relation of love with God through our participation in life and His sacrifice. This shows the quality and unique and unrepeatable value of the human person. A human action faithful to the demands of Our Lord, Jesus Christ's Gospel, will always claim from the "supreme truth" of the divine Person, who said of himself: "I am the way, the truth and the life" (Jn. 14:6) and revealed fully to the human being, called to partake of all the gifts of God.

Etymologically, the notion of truth was given several interpretations. If we start from the Hebrew verb "aman", formed from the word emet (truth), it means fundamentally the fact of "being solid"," being sure" or "trustworthy." In other words, the truth is the quality of what is stable, tested, solid, you can count on, that you can support. ${ }^{2}$ Jewish religious attitude does not admit doubt: Yahweh is sure, solid; He is the only one we can support. That's why are true the words he addressed to us through prophets, and they are received in faith. 
The Greeks were more skeptical; They do not get easily things they have not seen. The word they use to describe the truth, $\alpha \lambda \varepsilon \theta \varepsilon i \alpha$, consists of particle deprivation $\alpha$ and the word $\lambda \varepsilon \theta$ os or $\lambda \alpha \theta \circ \varsigma$, which means forgotten, hidden, which leads us to understand the truth as something that has been revealed, brought from the hidden and oblivion. Incidentally, this attitude toward truth is opposite to the one that certifies the Latin term veritas, which evokes rather a mystery.

The Slavonic language uses the word istina to describe the truth, meaning that is not just "what it exists" (in Latin est), but also which breathes (asti from the ancient Sanskrit). ${ }^{3}$ To know the truth means coming into contact with a living reality. This is the meaning of truth and in Romanian language, religious origin term that expresses the ultimate divine reality, that God's personality, whose presence is evident in creation (cf. Rom. 1:19) and fully communicated in Revelation. So the truth designate both the absolute and transcendent personality of God, His eternal substance, that can not be changed or justified, but only asserted: Oh my Lord, you are God and Your words are unchanged and hast promised your servant such a good. (II Kings 7:28) and the discovery or revelation of God's personality: "Truly this was the Son of God." (Mt 27:54).

Therefore, the truth is not an impersonal divine substance, or a religious or philosophical speculation content, but a personal existence that enters in history and becomes accessible to people. "The Word became flesh and made his dwelling among us, full of grace and truth" (Jn. 1:14). So the truth is not objectual, nor an abstract principle, but personal, it is a Person which manifests in the Person of Jesus Christ, the Son of God incarnated. In him, the fullness of truth is manifested integrally, because He is the Truth (Jn. 14:6;17:17) and in/through Him, the truth becomes "epiphanic" fully discovered, personalized and personified I am . . . the Truth (Jn. 14:6). So the truth is not a dead capital, but it kindles his soul or, more precisely, gives life and still "life in abundance." And depends on the person, the truth is life and dynamism; After all, only the truth validates, remaining the same yesterday, today and forever. (Hebrew 13:8) can still say, See, I am making all things new." (Rev. 21:5) 
Jesus Christ is the Truth in person: "No one has ever seen God; but the one and only Son who is himself God and is in closest relationship with the Father, has made him known "(Jn. 1:18). His life and ministry is a true epiphany of Truth which is revealed through the work of the Holy Spirit, who confirms Christ and gives certainty to the Truth: "When the Advocate comes, whom I will send to you from the Father, the Spirit of Truth, Who goes out the father, he will testify about me "(Jn. 15:26). Therefore, substantial knowledge of the Truth means the actual entry within the Trinitarian Divine, ${ }^{5}$ unity, as entry-communion-union, which makes possible the deification of man. For he who comes to know God's hypostatically truth, wants to live life "full of grace and truth" that flows in every creative and transfiguring act of his person. ${ }^{6}$

God's Word is "Truth" in love. The name "Truth" I am . . the Truth ... (Jn. 14:6) as that of the "Word" of God; the Word was with God and the Word was God" (Jn. 1:1) it is his own Son, because the Son is related to the Father as well as the definition is in relation to the defined ${ }^{7}$ subject. And the Spirit is the conquering power that opens the depths of truth and it turns into love, inspiration, freedom and beauty. "Love comes from God and everyone who loves has been born of God and knows God" (I Jn. 4:7). We can easily see that it is not a question of any change or any improvement of the one who loves, but rather a procession "of ( $\left.\varepsilon^{\kappa} \kappa\right)$ God", a sharing of the Holy Spirit, who revived the one who loves to a new life, passing it in a completely different state of reality, gaining a new existence. The one touched by the scented grace of the Holy Spirit and came to love truly, has passed from the kingdom of this world into the kingdom of God, that has appeared in the new world of the Truth, where it can grow and develop; God's seed remains in him, the seed of divine life (cf. I Jn. 3:9), the seed of Truth itself and of true knowledge.

From the love where the truth is missing, on the other hand, is missing all the gifts that the Son dwells in it, is missing its cosmic contents, such as the belief from which the Logos or the truth disappears, is remaining nothing but an unconscious enthusiasm. But knowing the truth, the one who believes genuine, understands the change that was made to him: "We know that we have passed from death to life, because we love each other; Anyone who does not 
love remains in death "(I Jn. 3:14). Mutual love is the only one that can be and is the condition of unanimity, of thinking unity between those who love each other in opposition to the exterior realities between people, which give just a similarity of thought, under which the world is based on life, science, society, state, etc. ${ }^{8}$ The unanimity provides the basis under which the common confession is possible, meaning the understanding and recognition of consubstantiality dogma. In other words, in/throught this unanimity we reach the mystery of the Trinitarian Godhead, who gives eternal life. For "Whosoever hates his brother is a murderer, and you know that no murderer has eternal life abiding in him" (I Jn. 3:15). And because the love of a brother is a kind of manifestation of divine power that radiates the one who loves God, "who does not have eternal life" is, in fact, the one that have not entered into the divine life of the Trinity and, as such, nor can love.

So, true love is the exit from empiric, and passing out in a new reality. Love for "another" is a reflection of true knowledge, projected upon him; ${ }^{9}$ and knowledge is revelation of the his own Tri-hypostatic Truth in the man's soul, that remain in the soul of God's love for man: No one has ever seen God, but if we love one another, God lives in us and his love is made complete in us. (I Jn. 4:12). This clearly shows that man has acquired, in the work of the Spirit, by grace, a new essence, which is to have a personal communication with God, as between father and son, and to enter into personal communion with God, achieving the confidence before God. (I Jn. 3:21).

Absolute truth in love is known. Love for "brother-neighbor" is a manifestation towards another, a pass on another, a kind of infiltration in another, of that penetration in the divine life, that the subject itself found in communion with God, it realizes as the knowledge of the Truth. It is the love that brings together two worlds: mine, self, which is deserted (Phil. 2:7), and of "another", of the other one, who became my way , my own, personal, of existence. ${ }^{10}$ And the greatness of this relationship, communion, is that here reveals the mystery, the mystery of the meeting, of the earthly image, passer, with eternal truth, which discovers love. And the end of love is: like two, to be one, a full unity, that "an ecclesia," a church. Here, in the Church, every I, becomes a whole by merging all, to one another in 
an all consubstantial. ${ }^{11}$ Thus was founded the Church or the "Body of Christ," understood as an objective revelation of divine love hypostasis. For this reason, the mystic John Scot Eriugena said: Love is the bond through which all things link in an inexpressible friendship and in an indivisible union. ${ }^{12}$ And this is exclusively the work of the Holy Spirit, which caress through the joy of contemplation, which is everywhere and fills all the treasures of goodness, which gives life and lives and, through His dwelling, cleans the world of every stain. ${ }^{13}$

This means that truth is a revelation of God-The Trinity made to man, that is a revelation, a manifestation of which is found clearly and fully in the Church. ${ }^{14}$ For truly is what it looks like. This means that we can call the truth as 'spirit' appearance, manifestation, revelation. In this perspective, the truth is identified with the Church. St. Gregory Palama says about this: Those who belong to the Church of Christ are of the truth, and those who are not of the truth, are not of the Church of Christ. ${ }^{15}$ And it is perfectly right, for the discovery of God and man's adept with divine grace deifying are equally true. And this truth is identified and is connected to the Church, the only one that shares the sanctifying grace of God, by administering Blessed Sacraments. Therefore, anyone who falls outside true expression of the truth or anyone who breaks the truth, falls from the communion of the Church. Here is what says St. Palama: "Let us therefore hold all the traditions of the Church, written and unwritten, and above all, the most mysterious and holy custom and adept of the Holy and Divine Liturgy, where we are given the communion of the Body and Blood of Christ. And all who does not confess and do not believe that the Holy Spirit spoke before the prophets, that the Lord incarnate gave us obvious commandments, that the apostles proclaimed that they had been sent by Him, that we received instruction from our parents and from our descendants, but instead they have started themselves any eres or they followed relentlessly on those who in a wicked way, they started the eres, we disown them and we give them to anathema." ${ }^{16}$ As we can easily see, this text reveals that those who lose Tradition of the Church, receiving no discovered experience, but by their own speculation are trying to compile other Tradition, they are removed by the Church and by counted, of course, 
the heretics. More specifically, the one who loses the true faith and breaks the bond with Christ, corrupting the truth of the Church and distinguished itself from the theology and life of the Church, is godless, and the lack of God is His ignorance and implicitly, is serving a God, different from the one who discovered us.

So the truth is identified and is closely linked to the Church, and the Orthodoxy is the true faith and the true Church, because in it man's salvation is assured. Ensuring the believer's salvation results from the salvation and living true faith, the right faith. Faith is the bond that makes arise unmediated, perfection and supernatural union, of the believer with God, in which he believes. Because faith is aimed at the salvation of souls: "Whoever believes and is baptized will be saved, but whoever does not believe will be condemned" (Mk. 16:16). Hence it is clear that those who lose faith, orthodoxy or true faith, lose also the union with God, deification, and split from the Church, which is the Body of Christ. Therefore, the Orthodoxy is the Church, the one who has the truth, the true faith of the Church, which retains true and sure art of healing and can guide man to the true knowledge of God, who is in communion with Him. In a word, the Church has the truth (I Tim. 3:15) and it is the only one offering man's guidance to the deification. In this way, the Orthodoxy is the Church simply.

I do not think we say great things and without support or coverage. Even I confess, that few people know today, that the Orthodox Church is nothing other than the Church that kept unbroken authentic teachings of Jesus Christ, teachings given to every generation of believers and lowered by the Apostles, clarified and expounded attentively to their offspring lawful, divine disciples of Apostles and church fathers, taught and kept by the Eastern Church, which is the only capable to prove their right to be called "Orthodox Church". The Divine Founder of the Church, our Lord Jesus Christ, made it clear that I will build my church and the gates of hell will not overcome it (Mt. 16:18) and admonishes the whole truth heralding the future (Jn. 16:13), shielding it from wandering. Truly it did all this over two millennia, proclaiming to people this truth, that God came into the world, to testify to the truth, and everyone on the side of truth listens to me (Jn. 18:37). St. Paul also testifies 
and says: "The church of the living God is the pillar and foundation of truth" (I Tim. 3:15). It follows that the true Christian church always existed on earth, and will exist until the end of times. It received the promise of Christ before His ascension with His body to heaven: "I am with you always, to the very end of the age" (Mt. 28:20). Can there be any doubt that the Lord refers to the Church here?

Any healthy and honest judgement, every work of a clean conscience and anyone knows the history of the Christian Church, moral teachings and theological clean and undistorted of the Christian religion, must confess that there was a true Church, founded and supported by our Lord Jesus Christ and that it kept His holy and unchanged Truth. Moreover, the history shows a bound of grace, that can be drawn, from the Apostles to their successors, where, the saints are living testimonies of sharing the source of grace and savior Jesus Christ. And since truth is given once and for all, our duty is rather to assimilate it, than to discover it. The true Church seeks to serve God and to save souls. However, from this perspective, we have the commandment to strengthen ourselves and others with Truth, in Jesus Christ, the fullness of divine truth.

\section{The Supreme Knowledge and the Fruit of Christian Education}

In the area of Latin and Greek spirituality and in the area of Christian patristic, the concept of education is, generally, almost identical to the concept of culture; often these concepts are identical. $\Pi \alpha \iota \delta \varepsilon\llcorner\alpha$ or $\pi \alpha i \delta \varepsilon v \sigma \iota \zeta$ same term means education and culture, both derived from the root of the word " $\pi \alpha \iota \zeta$ " which means "child".

In modern times, these notions are not covered and are not always dependent one on another. In our language, "being educated" does not necessarily imply culture and "being religious" does not also mean to be educated. For culture does not mean only the presence of a baggage of knowledge and lifestyle, automatically different from other ways of life, but pursuing the culmination of a long process of education began in childhood and progressive

enhancement whole life through knowledge, lectures, experiences 
and free effort and consciously to become better, more useful. It is true that education and culture resemble each other and sometimes identified by the fact that both involved a selection process and were the result of such a process.

In this process of education, Christianity holds an important role, who could not fulfill in history, and the cultural and moral progress of humanity so prominent if it had not fulfilled a pedagogical role. Religion is the mother of mankind's education, classical school of formation of moral and spiritual perfection character of man and human society. ${ }^{17}$ And because religion has made mankind's first education and the purpose of education is the virtue or the strength of character of morality, the Church pays great attention to Christian education, even education is a fundamental concern of the Christian Church. Church is the one that determines the educational factor to guide and lead man for clarity on him, toward peace with nature and toward union and knowledge of God. To do this, in the church, education aims to develop and representation as discerned of the image of God in man, up to full brightness similarity with God. For this purpose, the education in the Church is meant to raise man to know himself, the divinity knowledge and nature and the knowledge of a pure and holy life. ${ }^{18}$

In his major work, Didactica Magna, J. A. Comenius said that the ideal education is eternal life, that the religion is the perfect means by which we achieve human improving, society's perfection and eternal bliss in communion with God. Also, he starts from the idea that the model of all educators is Jesus Christ as Man, He is the most enlightened Teacher, holiest Priest and most powerful King. Therefore the Christians must be brought there to be enlightened in spirit, holy in conscience's inclinations and strong in deeds. ${ }^{19}$ This goal can be accomplished through education and personal virtue. For in Holy Scripture is the Word of God, His works are seen in the world, and the man's soul has in it divine inspiration.

Christianity is a system of perfectibility, a method of spiritual improvement, which envisages the synthesis of good, truth, beauty and the sacred, in the human person. Through education, man shapes and ennobles his character. The character is about the person. 
Created by God, being holy and having a certain value inside his core, the person has a free and creative will, which manifests itself as a system of actions, so that an empirical character. To that end, the person is character, ${ }^{20}$ and the human character is formed through education because man is perfectible, trainable. Therefore we say that education is aimed at human perfection, perfection consisting in love and holiness.

Being human means to be a perfect character, a moral personality. But moral character is not formed at once, because the will itself gradually develops. Everyone is born with a complex of psycho-physical endowments and lives in a certain environment. The moral character is a permanent conquest, based on the unrelenting effort of will until the moral personality is made up, which is the supreme incarnation of the moral ideal. Moral personality is the goal towards which all human efforts are lead, feeling that is the bearer of eternal values. Therefore the moral personality embodies, personally, the good, in a consistent and harmonious development of all beings and in creative participation to moral life of mankind by holiness, completely understood, morally. Or, perfection of character and moral personality, is made through education, which is the initiation into life and Christian teaching, which ultimately leads to holiness.

The unsurpassed model of holiness and divine perfection, incarnate in human form is Jesus Christ, the perfect man and teacher of mankind, man model, educator par excellence, and unique teacher of the truth: But you are not to be called Rabbi, for you have one teacher: your Christ! (Mt. 23:8-10), who gave Himself for instance that" as I have done for you, that you should do "(Jn. 13:15). Nobody discovered us and not taught better and more beautiful the true meaning of life, nor the perfect methods of education, as taught, by Jesus Christ. For this St. Clement of Alexandria refers to Jesus Christ as the educator, par excellence, of Christians. ${ }^{21}$ All people who tend to perfection, learn from Jesus how to gain salvation, how everybody must make efforts to achieve the salvation of his soul and body to perfection, the sanctification of the whole man.

The universality of Christian education results, from the universality of salvation. Supreme sacrifice of Jesus Christ on Calvary 
was brought to the whole human race, that was fallen into sin. By His Divine Resurrection, the gates of paradise have opened for all children of Adam. After the restoration of man by Jesus Christ, all people have a right to salvation, on condition that every man to trouble himself, through faith and good works, to be worthy to partake of the salvation brought by the Son of God. More so, since God desires all men to be saved ( I Tim. 2:4). For this, Christian Pedagogy is the hand of man on the paths of salvation, can not leave aside the most people and deal only with little kids, only children. The Christian pedagogy does not specifically deal with intellectual and physical training, which is essential to children, but she puts all the interest especially on the moral perfection of man. This absolutely people of all ages need, and especially the adults. In this sense we can say that the whole Christian teaching is a pedagogy, the whole work of the Church is nothing but an effort to raise man to a better state, from a moral point of view. (Eph. 4:13) So, for this reasons of soteriological order, the Church is dealing with the education of believers of all ages.

Of course that education begins in the family and turn their attention first to the child, since his arrival on the world, the child does not bring a formed morality, but is only endowed with moral virtualities. The imperious duty lies to the family, to develop the moral core of the child through education. Parents have an important role in cultivating the moral qualities of children, by transmiting them, through counsel and example of their lives, the moral skills and the first elements of the education. At this urges the Apostle Paul: Fathers, do not exasperate your children; instead, bring them up in the training and instruction of the Lord (Eph. 6:4). But this is really an art, to form the child's soul and mind of the young. In this respect St. John Chrysostom says: "Which art can be equated with the art of educating the soul of the child, to shape the young's minds? ${ }^{22}$ In the sanctuary of life, which is family, the man since he is young or child, receives the first crucial notions about the truth and good, develops healthy the capacity to become aware of his dignity and prepare to face his unique and irreplaceable destiny in the world and society. 
Between the members of the family, of course, founded by marriage, is born, a kind of perichoresis, the meeting and sharing with one another, ${ }^{23}$ the family becoming a synthesis, and her mission in the society, a symphony. For the members of the family receiving Christ who unites them, inhabit together, configuring one after another, resting spiritually each other, ${ }^{24}$ and enrich each other through love. So did God. We are born, usually, in a bipolar matrix (parental couple); we continue the great adventure of our existence, becoming ourselves polarizing figures, male and female, self-conscious psychosexual identity; then we aspire to the archetypal structure (male-female), based on polarity principles, on complementarity, seeking the partner with which to develop (sexual, emotional, mental and spiritual), one through the other. ${ }^{25}$ Therefore, the family is the gravity center of Community existence, the first and most important in this respect, while being common to people who comprise it, different from other people, absolutely unique, just as each person is unique and each conjugal being is unique. ${ }^{26}$ Therefore natural family focuses on all values through which affirms itself and sustains life, it shapes the original skills, the man's soul and body, as do to the existence of good, to increase and to be transmitted from generation to generation, as forms of culture and civilization.

Maybe that's why God has allowed to be born, to grow and to form children in families. Here, the role of parents in raising and educating children in virtue, requires an imperative of salvation: "For the children come into the world not only to support parents at elderness, but for them to learn the virtue from their parents" (27). Parents are true teachers of children, which are rooting in their hearts "profound love" through education.

From the bosom of family life, through a long and arduous learning process, all ages benefit: youth here develops, mature age here ensures its fecundity of elderness, family allow him a supplement of hapyness, a support, an extension of thanksgiving for won victories in the tumult of the elders existence. Therefore, if we look at the importance of family in general education process, both for individuals and for society, and we find that the family is the man, and its functioning means life, is to realize that the truths that underlie at the basis of the family and Christian education, must 
be regarded as having an absolute value that we can not repudiate, without repudiating ourselves, our humanity and nature.

From the religious point of view, the family is the training lab or rather, of discovery, for the child, of the divine-human universe. Not coincidentally, the popular wisdom speaks of the "seven years of childhood" that leave their mark on everyone, for life. It is understood that the religious education received at school or in society can not be effective unless the family atmosphere, the environment in which the child lives, enter into confrontation with the heard and seen ones. For instance, if at school, at religion classes, children learn that it is a mistake, a sin, before God, the adultery, to steal or to lie, and at their parents they see the opposite, then their confusion would be hopeless. Equally, the exercise of prayer, of the Christian behavior according to the biblical precepts, or applying the teachings given by the Savior through His parables, however all these will never be efficient for the education and a child's life if they were not staged, repeated and lived daily at the existential mini-laboratory level, which is family. And this can not be achieved without close supervision of parents.

The example of the parents has a decisive role in shaping children's religious habits, translating into concrete vivid acts, the abstract formula of debt. Thus, parents should do their prayers with the children, be taken regularly to church, learn to make the sign of the Holy Cross, kneel, sing religious songs, to bring gifts to the Holy Shrine, to light candles for the living and the dead, as often to partake of the Holy Mysteries of Christ, and, thus, to be among the faithful. This is also because the Christian family is included in the mission of the Church; It is an extension of the Church in the world and bringing the world into the Church.

It is no longer a secret to anyone that in today's world, in modern and modernized societies, most young people prefer not to marry, opting for passing relations, unconventional-marriages for a day, or rather of "one night" or "on probation," celebrated around "Valentine's Day" - and without social commitment (to children, for example) or irresponsible, symptom of reverting to traditional, Christian and secular values. Because more young people today are asking: "Why marry?" And this precisely because nobody opened 
their eyes in this regard. Not infrequently young people see that their parents no longer love eachother, get divorce, or that they live together only because of social conventions; to deceive each other, or one is cheating and the other is suffering and leaving himself to drunkenness, discouragement or depersonalization. Such families, of course, represent nothing attractive. And then they ask themselves questions like: "That's a family?" The answer unequivocally: "We do not need that!" They deny the family whose image they know, and they're right. Who would choose to destroy their happiness only to be like the others, to be among the world? In a theological vision, this phenomenon appears as an ultimate consequence of sin, understood as a waiver of any responsibility before God and the human community.

A process as seriously is the rapid dissolution of most families conventionally constituted, sometimes even formally passed through the ritual sacrament of matrimony. The fact is all the more painful, the more of marriage seems to be understood in its size, by the ascetic commitment for the realization of a communion of increasingly perfect among family members. Marriages crumble for reasons as ridiculous and superficial as for that contact, betraying, most often, pecuniary interests, confusion between eroticism and love, untamed passions, instability of mind, etc.

In these cases, no more talk of the traditional family, carrier and guarantor of values, of practical wisdom and much less about a family able to propose and support the leap to the superior survival to all family members, in the likeness of God. Moreover, it seems that what until now was known as "basic cell" of the social organism, the family can no longer perform any real function, social body basing only on individuals. But the matters of concern here is the loss of the family of its educational function. Theologically speaking, this loss is a consequence of abandoning the grounds of Christian life and family.

Starting to be a factor of education, families or even casual relationships produce constantly children, who increasing without receiving the easiest parts to build a decent life, unwittingly contribute to amplifying the drama. Because almost completely devoid of axiological and ethical criteria, children and youth now, 
bewildered, indifferent to those around them and deprived of a sense of personal responsibility, contribute to modern society-which declares to be in transit to a post-Christian era-and return to the era of migrations beyond the myriad of civilization.

In this context we are witnessing a reversal of educational values, where the moral law is discredited and in which man tends to become (or even became) a servant of matter, cold and metallic character of technical civilization, quashing the soul and last sigh after God, the Church is called to do Christian education and through it to guide the spiritual children, enrolling them on the path of holy love. This is because in a desecrated and secular society, like the current one, only the Church can make religious education because it is the place where believers are sharing the life and truth of God, where all are united in the "mystical body" of Lord, embedding responsibly and saviour through Holy Baptism and where they receive as food his divine body broken on the cross and His shed blood as a clean sacrifice for them in the deepest humility and love. In this sense the Church is and must remain preoccupied with moral, behavior and salvation of its children's soul, the educational issues raised by today's society; it must remain deeply rooted in the practical life of its members, looking towards the divine, developing always moral and educational values as virtue, developing a sense of duty and responsibility, and worrying about the big problems that arise within the current society: justice, peace, family, person, society, solidarity.

The problem of the educability of the human person depends of the anthropological conception, namely the idea that somebody makes about human being and purpose or mission of the man. Karl Weiss, the german teacher says, rightly, that in a way he conseive the theory of education a materialist, in another way a deist, in other a pantheist, a believer and a Christian otherwise. ${ }^{28}$ In other words, the types of education differ by type of anthropological conceptions. If we go further, we can state that in Christianity, the types of education can be classified after confessions; one education receives an Orthodox, other education an Catholic, other education a Protestant. In this sense we say that the great Church Father, St. John Chrysostom, has a conception of man and education, eminently the 
orthodox Christian. He has a very high opinion of man. For him, the man is more honorable than all beings seen. Nothing is so precious that man; the whole world did not equals him. God made all because of His love for people. He created all humans. If anyone should carefully investigate all the Creator commits every day for us, he would find an abyss of His love for people. Its privileged situation of rational and ruling the world being, man owes the love for God's people. ${ }^{29}$ Perfectly true statement, as in human being, where it meets both the spiritual and the material part, contain the entire creation, which is why it is called "microcosm".

Such a conception of man, not only it makes possible the education, but requires just as a necessary. The symbiosis of body and soul requires collaboration in the sense of mutual perfection. Unlike God, who's work in education can not be applied, because He is unchanging nature, can be applied to humans, because is changing its nature and because the educability is integral nature to human being. But we understand that the education is not a simple increase in certain sense of the man. Education is a systematic work of the whole human beings to awaken, develop and strengthen all internal powers in a free and conscious way to get to know the Divine. St. John Chrysostom has the merit to underline in his works, repeatedly, that man is free and conscious subject of education, because it is endowed with reason and freedom of choice. ${ }^{30}$ At the same time, he is convinced that good will overcome evil. The struggle is hard and long, but the result can not be doubtful. The transformation of a human being fallen into a person with purple robe with a crown, is something extremely difficult, but still possible.

Therefore, education is a fundamental duty to man, it aims to make from man a moral being just and pious, being a high and noble art, because it is done also to the future world. There man will know the whole truth, then his eyes of his soul will open and will see clearly the fullness of the soul of whom he believed and followed in this life, weaving the garment of virtues after the Perfect Image of the Immortal and forever alive-Jesus Christ" our Easter ". 
NOTES:

${ }^{2} \mathrm{Cf}$. Tomas Spidlik, The Spirituality of the Christian East. The man and his destiny in russian religious philosophy, (Romanian translation by Maria Cornelia Ică jr., Edit. Deisis, Sibiu, 2002), 70.

${ }^{3}$ See Pavel Florenscki, The Pillar and Ground of the Truth, II Letter, (rom. translation by Emil Iordache, Pr. Iulian Friptu, Pr. Dimitrie Popescu, Edit. Polirom, 1999), 17-18. 1994), 10.

${ }^{4}$ Pr. prof. dr. Ion Bria, Dictionary of Theology, (Edit. IBM of BOR, Bucharest,

${ }^{5} \mathrm{Cf}$. Pavel Florenski, The pillar and Ground of the Truth, 53.

${ }^{6}$ Ibidem.

${ }^{7}$ Cf. Sfântul Grigorie de Nazianz, apud Pr. prof. Ilie Moldovan, Love, Mystery of Marriage-Love Theology, (vol. I, Alba Iulia, 1996), 48.

${ }^{8}$ Pavel Florensky, op. cit., 61.

${ }^{9}$ Avva Evagrie Ponticul says: „Love is the door to knowledge” (Evagrie, Le traite pratique, VI, apud Tomas Spidlik, op. cit., 83). Expanding his life through each other's life, through love for him, the person achieves "living knowledge" unseparated knowledge of reality, but imbued it. Thus, out of love we can not know any unit or truth. Because those are closely linked; they do not separate until love is missing.

${ }^{10}$ And because love is considered the principle of knowing the truth, it is the source and guarantee of truth, which is found in the communion of love or in Catholicity. By the force of this love, the entire reality and all truth appear united as a totality.

${ }^{11}$ St. Paul speaks of our "identification" to Christ through love, identification which does not destroy its own personality, but supposes: "I no longer live, but Christ lives in me" (Gal. 2:20). Love unites us to Christ and through Christ to the entire collective knowledge, with the universal experience of the Church.

${ }^{12}$ John Scot Eriugena, De divisione naturae, I, 74, apud Pavel Florensky, op. cit., 67.

${ }^{13}$ See the rudiments prayers dedicated to the Holy Spirit: "Heavenly King, Comforter, Spirit of Truth, Who is everywhere and all do it; Treasury of good things and Giver of life, come and dwell in us and clean us of all impurity, and save our souls." Cf. Ceaslov, Book that includes different prayers, ordinances and church services, (Ed. IV, Ed. IBM's BOR, Bucharest, 1990), 8.

${ }^{14}$ In the Church, the Trinitarian truth is revealed clearly. The truth is the contemplation of Himself by Other, a Third: the Father through the Son in the Holy Spirit. Because theTruth being, is the infinite act of Three in Unit.

${ }^{15}$ Sfântul Grigorie Palama, apud Mitropolitul Hierotheos Vlachos, The Mind of the Orthodox Church, (rom. translation by C-tin Făgețan, Edit. Sofia, Bucharest, 2000), 61.

${ }^{16} \mathrm{Cf}$. ibidem.

${ }^{17}$ Ilarion V. Felea, The religion of culture, (Edit. Romanian Orthodox Episcopate of Arad, Arad, 1994), 246-247. The famous French educator J.J. 
Rousseau said about the role of religion in education in the following: "Forgetfulness of religion leads to forgetting human debt... Therefore we must not forget that the soul is as true temple of deity; that the supreme law is to love God above all and your neighbor as yourself; that no religion saves you from moral debt; only those debts that are truly essential; as intern cult is the first duty and that without faith there is no real virtue." (JJ Rousseau, Emil's Education, Book IV, ch. 354, in trad. rom. Gheorghe Adamescu, Ed. IV, Bucharest, 618). Also the great poet, thinker and German educator I.W. Goethe: "The Christian religion is the religion incarnated in deity and is the highest gear that could and should arrive humanity". (Ilarion V. Felea, The Religion of Culture, 249).

${ }^{18}$ In this sense Fr. Froebel writes: "The most perfect conpletion that we, as Christians, see in Jesus and that humanity knows, it is the one of recognizing clearly and vivid in itself the prime basis of his being, which spontaneously and independently occurs by eternal stipulation, after eternal law, of eternal life and eternal creation. And this great and eternal perfection itself requires every man to become such a copy and an image of the eternal model, as he himself become such a model for him and for others... Yes, this is the theme and purpose of the whole moral education: the representation of the infinite in the finite, the eternal in the temporal, of heavenly in the earthly, the divine in man, in human life through the care of the originating divine being in all aspects." (G. G. Antonescu \& V.P. Nicolau, Education of humanity, Bucharest, 1965, 309.)

${ }^{19}$ Cf. Ilarion V. Felea, op. cit., 247.)

${ }^{20}$ Pavel Florenski, The Pillar and Ground of the Truth, 139.

${ }^{21}$ See Clement Alexandrinul, The Pedagogue, in rom translation by Pr. Dumitru Fecioru, in PSB collection, vol. 4, Edit. IBM of BOR, Bucharest, 1982.

${ }^{22}$ St. John Chrysostom, Homilies on the Gospel of Matthew, LIX, VII rom. Transl. Pr. Dumitru Fecioru vol: Writings, Part III, col. PSB vol. 23, Edit. IBM's BOR, Bucharest, 1989, 695.

${ }^{23}$ P.S. Vasile, the Bishop of Oradea, "Guidance on the Marriage of Young Theologians" in Mitropolitan of Banat, no. 1-2/1983, 78.

${ }^{24}$ P.S. Vasile, the Bishop of Oradea, "Guidance on the Marriage of Young Theologians" in Mitropolitan of Banat, no. 1-2/1983, 78.

${ }^{25}$ P.S. Vasile, the Bishop of Oradei, "Guidance on the Marriage of Young Theologians" in Mitropolitan of Banat, no. 1-2/1983, 78.

${ }^{26}$ P.S. Vasile, the Bishop of Oradea, "Guidance on the Marriage of Young Theologians" in Mitropolitan of Banat, no. 1-2/1983, 78.

${ }^{27}$ St. John Chrysostom, Homily $X$ to the Thessalonians, XIII, cited David C. Ford, The man and woman in the vision of St. John Chrysostom, Edit. Sofia, Bucharest, 2004, 106.

${ }^{28}$ Dr. Karl Weiss, Die Erziehunglehre der Drei Kapadozier, in „Strassburger Theologische Studien", Freiburg im Breisgau, 1903, p. 6.

${ }^{29}$ St. John Chrysostom, Homily on Genesis 8.2; 3.3 homilies; 10.7; Genesis

12.4 - Migne, P. G. 53, col 71,85,89,103 cited

${ }^{30}$ Pr. Prof. Ioan G. Coman, The beauties of love to people, 38. 


\section{BIBLIOGRAPHY}

Antonesc, G.G. \& Nicolau, V.P. Nicolau, Human education, (Bucharest, 1965).

Bria, Pr. prof. dr. Ion, Dictionary of Orthodox Theology, (Edition IBM of BOR, Bucharest, 1994).

Clement Alexandrinul, The Pedagogue, (in rom. trans. by Pr. Dumitru Fecioru, in colection PSB, vol. 4, Edit. IBM of BOR, Bucharest, 1982).

Coman, Pr. prof. Ioan G., Fathers fight against slavery, in „Theological Studies”, No. 3-4, 1953.

Coman, Pr. prof. Ioan G., News of St. John Chrysostom, in "Theological Studies" no. 7-8/1955.

Evdokimov, Paul, The ages of the spiritual lives, (in rom. trans. by Pr. prof. Ion Buga, Christian philanthropic medical Association Christiana, Bucharest, 1993).

Evola, Julius, Individual and beggining of the world, (in rom. transl. by Alexandru Săndulescu, Edition Anastasia, Bucharest, 1999).

Felea, Ilarion V., Religion of culture, (Edition of the Romanian Orthodox Diocese of Arad, Arad, 1994).

Florenski, Pavel, The Pillar ang Ground of the Truth, II Letter, (in rom. transl. by Emil Iordache, Pr. Iulian Friptu, Pr. Dimitrie Popescu, Edition Polirom, 1999).

Ford, David C., The man and the woman in the vision of the Saint John Chrysostom, (Edition Sofia, Bucharest, 2004).

Ică, Ioan I. jr. \& MARANI, Germano, Social Thought of the Church, (Edition Deisis, Sibiu, 2002).

Ioan, Saint John Chrysostom, Homilies on the Gospel of Matthew, LIX, VII, (in rom. transl. by Pr. Dumitru Fecioru in vol: Writings, part III, col. PSB vol. 23, Edit. IBM of BOR, Bucharest, 1989).

Mantzaridis, Prof. dr. Georgios I., Chritian Morality, (in rom. transl. by diac. drd. Cornel Constantin Coman, Edition Bizantină, Bucharest, 2006).

Moldovan, Pr. prof. univ. Ilie, Family and life at the beginning of a new christian millennium, (Edition IBM of BOR, Bucharest, 2002).

Papuc, Magistrand Gheorghe, Christian life after the epistles of the Apostle Paul, in „Theological Studies", No. 5-6, 1955.

Paul, Adrian Gh., Introduction in the Studies of Moral Theology, (Edition Mega, Cluj-Napoca, 2006).

Răzuş, Pr. prof. dr. Petru, Christian responsibility to the world, in „Ortodoxia”, no. 2 / 1972.

Soare, Pr. dr. Gh., Aspects of the Byzantine legislation related to man's protection in Theological Studies, No. 1-2, 1958.

Spânu, Pr dr. Domițian, Social suffering and Christ, (Edition Glasul Bucovinei, Cernăuți, 1925).

Spidlik, Tomas, The spirituality of the Christian East. The man and his destiny in Russian religious philosophy, (in rom. transl. by Maria Cornelia Ică jr., Edition Deisis, Sibiu, 2002). 
Stăniloae, Pr. prof. dr. Dumitru, Orthodox Dogmatic Theology, vol. III, (Edition IBM of BOR, Bucharest, 1978).

Vlachos, Mitropolitul Hierotheos, The Mind of the Orthodox Church, (in rom. transl. By Constantin Făgețan, Edition Sofia, Bucharest, 2000).

Zăgrean, Arhid. prof. dr. Ioan, The Active Sense of Christian Love, in Mitropolia Ardealului, no. 4-6 / 1970. 